\title{
Epistemologias e teorias do conhecimento em educação e educação física: reações aos pós-modernismos
}

\author{
Doutora em Educação pela Unicamp e professora da UFBA \\ Joelma de Oliveira Albuquerque \\ Doutoranda em Educação pela Unicamp e professora da UFAL
}

Celi Nelza Zülke Taffarel

\section{Resumo}

Este texto tem como objetivo apresentar uma discussão sobre a epistemologia e as teorias do conhecimento da pesquisa em Educação e Educação Física, explicitando as reações aos pós-modernismos. Apresenta as correntes pósmodernistas que vem influenciando estas áreas e localiza as diversas viradas epistemológicas, tais como a "virada linguistica" "hermenêutica" e "pragmática". Resgata a ontologia como base que da o sentido a essas reações contras essas "viradas" e busca mostrar as teorias do conhecimento e as perspectivas histórico-sociais que estão em confronto.

Palavras-chave: Epistemologia; Pesquisa Educacional; Educação Física; PósModernismos.

\begin{abstract}
This text aims to present a discussion of epistemology and theories of knowledge of research in Education and Physical Education, explaining reactions to post-modernism. Displays the current post-modernists who has influenced these areas and locates the various epistemological turns, such as the "linguistic turn" hermeneutics "and" pragmatic. Rescues the ontology as the basis for the sense of these reactions against these "turns" and seeks to demonstrate the theories of knowledge and historical and social perspectives that are in dispute.
\end{abstract}

Keywords: Epistemology; Educational Research; Physical Education; PostModernism. 


\section{Introdução: contextualizando o debate}

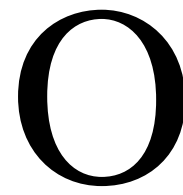

presente debate está sendo travado no momento em que a humanidade, perplexa, se depara com mais uma das profundas crises do capital, o qual busca se recompor, e obter cada vez mais, exorbitantes taxas de lucro, baseando-se no roubo legalmente estabelecido pela propriedade privada dos meios de produção da vida, e pelo alienante trabalho assalariado subsumido ao capital - nova forma de escravidão -, no contexto do parasitário complexo econômico especulativo, que está aniquilando a humanidade (Martins, 1999).

Situamos o contexto conjuntural e estrutural da crise para justificarmos a relevância das reações às teorias pós-modernas - ao irracionalismo, aos "giros" ou "viradas" idealistas -, imposturas intelectuais e recuo teórico que vem desarmando a classe trabalhadora no campo e na cidade, contribuindo para a alienação e para a contra-revolução.

O debate ocorre no tempo histórico de levantes na América Latina pátria mãe que sofreu séculos de violência, a qual não deixou um dia sequer, de lutar pela sua autonomia, independência e soberania perante os países imperialistas (Salazar, 2006). Dá-se também no momento em que nela movem-se as forças que querem ver suas reivindicações históricas atendidas, romper com o neo-colonialismo, e com imperialismo; no momento em que os balanços e avaliações da educação demonstram que, apesar dos esforços empreendidos, sob o marco das políticas neoliberais, compensatórias, focais e assistencialistas, a educação fracassou (Melo, 2004).

O debate se trava também, no momento em que se constata que o padrão cultural esportivo da população brasileira não foi elevado; acontece em um tempo em que ainda ecoa a voz de Che Guevara no Plenário das Nações Unidas: Já soou a última hora do colonialismo e milhões de habitantes da África, Ásia, e América Latina levantam-se, buscando uma nova vida e impondo seu direito irrestrito à autodeterminação e ao desenvolvimento independente de suas nações (Guevara, Assembléia da 
ONU, $1964^{1}$ ); também Josué de Casto, ao receber um prêmio internacional declara: Eu, que recebi um prêmio internacional de paz, penso que, infelizmente, não há outra solução que a violência para América Latina. Cento e vinte milhões de crianças se agitam no centro desta tormenta (Castro apud Galeano, 1979, p. 15).

O III Seminário de Epistemologia e Teorias da Educação - EPISTED e o IV Colóquio de Epistemologia da Educação Física, tiveram como objetivos [...] sistematizar, analisar e socializar a produção científica da área, assim como manter um permanente debate sobre a problemática que a identifica [...]. As temáticas delimitadas resultaram da consideração do que foi desenvolvido no II Episted e III Colóquio: problemáticas filosóficas da Educação e da Educação Física e a discussão acerca das tendências epistemológicas e pedagógicas das pesquisas atuais desenvolvidas nesses campos do conhecimento, particularmente o debate sobre os "giros epistemológicos" e suas repercussões na pesquisa educacional. Estas temáticas foram aprofundadas em mesas redondas durante o XV Congresso Brasileiro de Ciências do Esporte, (Recife, 2007), no qual foi sugerida sua ampliação, considerando a relação com as teorias do conhecimento e seus desdobramentos na controvérsia epistemológica contemporânea entre modernidade e pós-modernidade, assim como as reações à denominada "virada lingüística". Apresentamos, portanto, uma delimitação do tema, para que não recaia sobre uma única conferência a grandiosidade das pretensões dos organizadores, destacando que os limites temporais e teóricos são muitos.

Para organizar o debate sobre as correntes pós-modernistas que vêm influenciando a pesquisa em Educação e Educação Física, localizamos o que são os "giros" ou as "viradas lingüísticas", a saber, a viradas "hermenêutica", "pragmática", e o resgate da "ontologia"; qual o sentido das diversas reações, a partir da ponderação das teorias de conhecimento, e das perspectivas histórico-sociais em confronto. Explicitamos, também o

\footnotetext{
${ }^{1}$ Vídeo disponível em: http://cafehistoria.ning.com/video/che-guevara-onu-1964. Acessado em: 10 de outubro de 2008.
} 
que é o irracionalismo, o pós-modernismo, os "giros" ou "viradas" idealistas e as reações daí advindas, questionando conceitos, explicitando interesses subjacentes à defesa da irracionalidade, do subjetivismo, dos particularismos, e do fragmentarismo, levantando hipóteses sobre o status da teorização na Educação no Brasil.

Considerando que a concepção materialista dialética da história é extremamente atual, vamos nos valer de categorias analíticas que explicitam, desvelam, explicam e permitem a ação em um contexto de relações, nexos e determinações, para reagir ao pós-modernismo enquanto uma corrente contra-revolucionária. Segundo Lombardi, (2003, p.IX) a categoria que melhor expressa o conjunto de relações implicadas na atual produção e reprodução da existência dos homens é o modo capitalista de produção; a categoria mais precisa para expressar a atual fase das relações capitalistas entre diferentes povos e nações não é globalização, mas imperialismo; as categorias que melhor expressam a forma de organização capitalista nesta fase não são 'mercado' ou 'concorrência', mas concentração da produção e monopolização. Ademais, a melhor categoria para expressar a essência do próprio capital, que nesta atual fase domina e controla a própria acumulação, é capital financeiro. Acrescento, conforme aponta Trotsky $\left(1923^{2}\right)$, que a melhor categoria, para explicar as relações entre indivíduo-gênero decorrente da formação econômica atual, é modo de vida; e por fim, a melhor categoria para discutir teoria do conhecimento é organização do trabalho de produção da ciência. Sendo assim, as hipóteses a serem confrontadas no decorrer do texto são as seguintes:

1) Prevalecem hegemonicamente no Brasil teorias reformistas, antirevolucionárias, tanto na produção do conhecimento quanto nos subsídios de políticas públicas nas áreas de Educação, Educação Física e Esporte. Isto é constatado nos aportes teóricos mencionados nos textos, relatórios, projetos, programas e demais documentos, nos quais são silenciados os aspectos referentes às leis gerais que regem o modo do capital organizar a

\footnotetext{
${ }^{2}$ Disponível em: http://www2.cddc.vt.edu/marxists/portugues/trotsky/1923/vida/index.htm. Titulo Original: Les questions du mode de vie, Léon Trotsky. Lisboa: Edições Antídoto, edição: nº44 1 edição: Maio 1979.
} 
vida; ao Estado burguês e à necessidade histórica de derrubá-lo; aos hábitos de vida burguesa em família e a necessidade de destruí-los; e, à estratégia e tática na luta de classes para superação do capitalismo rumo ao comunismo; 2) É necessário avançar, reagir, resistir, através de rupturas e saltos qualitativos, para novas sínteses em patamares teórico-práticos mais elevados, superando os desvios teóricos, rompendo ilusões, lutando contra o fetichismo, o irracionalismo e o idealismo, buscando a referência clássica marxista;

3) Existem reações sim, na luta concreta, onde se buscam construir e erguer outros pilares para a produção do conhecimento científico e para a escolarização, e esses pilares já podem ser reconhecidos: o combate ao irracionalismo, ao pós-modernismo, aos "giros" e "viradas" idealistas, buscando consolidar uma consistente base teórica marxista, avançar na consciência de classe, na formação política e na organização revolucionária, como contraponto aos pilares da educação defendidos pela UNESCO para o mundo;

4) Ventos de esquerda ainda sopram na América Latina, contraditoriamente, e o marxismo, enquanto filosofia, o materialismo histórico dialético enquanto epistemologia e, o socialismo enquanto projeto histórico, eles estão recolocados mais fortes do que nunca, pela sua aderência ao real, como referência para tratarmos da produção do conhecimento científico e das políticas públicas na perspectiva do projeto histórico para além do capital.

As ponderações e confrontos entre as correntes "pós-modernistas" e as reações às mesmas serão explicitadas, para que os pesquisadores não somente se apropriem criticamente de ferramentas de análise e/ou superarem modismos, desvios e posturas ingênuas que produzem dispersões e diluem a capacidade de aprofundamento na compreensão das práticas pedagógicas, como também, para que sejam avaliadas as dramáticas consequiências sociais de tais posições teóricas, e para que se fortaleçam compromissos históricos dos pesquisadores e educadores, tal como o é a emancipação humana, a saber, com o projeto histórico comunista. 


\section{Os "giros" ou o embate entre idealismo e materialismo}

Para compreensão dos "Giros" ou "viradas", iremos nos valer de sínteses apresentadas por Sánchez Gamboa $(2009-a)^{3}$, quando o mesmo ressalta que existem duas grandes possibilidades históricas do ser humano conhecer o real: ou pela via do idealismo, que pressupõe a consciência acima do real, a existência de seres acima do ser humano que criaram a natureza e os seres, que pressupõe o Absoluto; ou, o materialismo que pressupõe as relações entre matéria e consciência, em tempos, espaços e movimentos, segundo leis, relações, nexos e determinações recíprocas e concretas da existência, e por meio do intercâmbio do ser humano com a natureza para manter a vida conhecer, e assim, constituir a história. Lembremos que, enquanto seres humanos fomos um dia subsumidos por leis físicas e biológicas. Porém a linha do tempo e da luta pela vida permitiu saltos qualitativos, e hoje prevalecem as leis sócio-históricas.

As formulações em torno dos "giros", ou seja, formulações para superar contradições teóricas localizadas em paradigmas e abordagens anteriores, se dão durante o breve século vinte, um dos mais devastadores e mortais que a humanidade viveu. Isto pode ser comprovado nas duas grandes guerras mundiais e seus mortíferos aparatos, entre os quais, constam como política, os regimes fascista e nazista, e as ditaduras de Estado e militar; e, como arma, a bomba atômica, capaz de destruir o planeta, mas incapaz de reconstruí-lo de uma única vez (Hobsbawm, 1995).

No momento em que estão sendo levantadas as principais hipóteses do esgotamento das teorias educacionais e pedagógicas, nos encontramos para debater as reações aos pós-modernismos. Uma teoria se esgota quando não explica e atua no real (Souza, 1997). E entre as hipóteses do esgotamento da teoria, constam as formulações e explicações dos pós-modernos que silenciam sobre as leis gerais de desenvolvimento da natureza e da

\footnotetext{
${ }^{3}$ Disponível em: O debate da pós-modernidade: as teorias do conhecimento em jogo. S/da. disponível em: http://www.cbce.org.br/br/gtt/texto.asp?id=4; e Reações ao giro lingüístico. Apresentação. $\quad \mathrm{S} / \mathrm{d} \quad-\mathrm{b} . \quad$ Disponível em: http://www.cbce.org.br/upload/file/gttepistemologia/REAÇÕES\%20AO\%20GIRO\%20LIN GUÍSTICO\%20Silvio\%20Sánchez\%20Gamboa.pdf.
} 
sociedade, as leis gerais do capital, a natureza e o combate ao Estado burguês e, silenciam sobre as táticas e estratégias da luta de classes para transformar a atual formação econômica em uma nova e superior forma de organizar os meios de produzir e reproduzir a vida.

Portanto, para criticarmos as teorias, fruto do trabalho humano no processo sistemático e rigoroso de produção do conhecimento, é necessário resgatar o caráter ontológico da produção do conhecimento e distinguir as formas em que se apresentam a atividade produtiva do homem e compreendermos o grau de alienação do trabalho: trabalho em sua acepção geral - como 'atividade produtiva': a determinação ontológica fundamental da 'humanidade'[...]; e em sua acepção particular, na forma de 'divisão do trabalho' capitalista. É nesta última forma, que o 'trabalho' é a base de toda a alienação (Mészáros, 2006, p.78). (Grifos do autor).

Mas afinal, o que impede o homem de realizar sua atividade produtiva de forma não alienada, ou seja, o impede de satisfazer suas necessidades de forma emancipada? Marx demonstrou em "O Capital” que é a propriedade privada dos meios de produção - o intercâmbio - e a divisão do trabalho. $\mathrm{O}$ homem, a partir destas mediações, se aliena do próprio trabalho; da matéria a que se aplica o trabalho; bem como, dos instrumentos do trabalho. Ocorre no modo de produção do capital uma mediação de segunda ordem - forma específica, alienada, da automediação ontologicamente fundamental do homem com a natureza (mediação de primeira ordem) (Mészáros, 2006, p.78).

Como referência para a elaboração do conhecimento científico, partimos da mediação de primeira ordem, o que implica considerar a forma com a qual os homens produzem os bens necessários à vida, ou seja, considerar o trabalho enquanto a atividade humana que transforma a natureza nos bens necessários à reprodução social.

Para compreender, portanto, como se dão as mediações de segunda ordem na produção científica, consideramos as fragilidades do modo de produção em que estamos inseridos: a destruição e/ou a precarização da força humana que trabalha e a degradação crescente do meio ambiente, na 
relação metabólica entre homem, tecnologia e natureza, derrubando a tese de que o que está alavancando a reestruturação produtiva é a ciência e a tecnologia. Isto é uma ilusão. Bonotto (1997) aponta que, o fator real que está alavancando a chamada reestruturação produtiva é o controle do trabalho por parte do capital.

Enquanto isso, os idealistas argumentam que vivemos na "sociedade do conhecimento", e que o simples acesso ao conhecimento garantiria o progresso, o desenvolvimento, a empregabilidade. Segundo o autor, o que ocorre é a apropriação privada do conhecimento científico e tecnológico, e portanto, as novas tecnologias não são difundidas pelo fato de serem substancialmente novas, ou boas para as pessoas, mas sim, por permitirem um controle ainda maior do processo produtivo pelo capital. Diante desta problemática, aponta que o desenvolvimento da dialética, a generalização dialética das lógicas não-clássicas, e o acúmulo científico dos trabalhadores indicam caminhos para a implementação de melhores métodos produtivos (Idem, p.72).

É preciso, portanto, compreender: por que se nega o conhecimento e as ferramentas, os instrumentos, para a produção do conhecimento científico? Porque são necessários ao capital os desvios teóricos, as ilusões, os giros e viradas idealistas?

Entendemos que esses problemas são produtos da materialização das estratégias que o capital se vale para manter sua determinação mais profunda que é a sua expansão e a acumulação, através da extração e acumulação de trabalho excedente, e o faz através da mediação do Estado e suas medidas que aprofundam o acirramento da luta entre as classes (Mészáros, 2002, p.100). As mediações do Estado se expressam nas reformas e nas novas leis decorrentes destas primeiras. Entre elas destacamos a questão da educação via escolarização da classe trabalhadora e as estratégias do capital de educar para o consenso. Neves (2005), demonstrou que a ampliação do Estado Brasileiro a partir dos anos de 1980, no contexto de implementação e aprofundamento do modelo societário neoliberal, vem se dando por meio de um programa político específico - a 
Terceira Via -, que visa educar para o consenso sobre os sentidos de democracia, cidadania, ética e participação, adequados aos interesses privados do grande capital nacional e internacional.

Assim, o conhecimento, na sociedade do capital, adquire força produtiva - quando, o conhecimento produzido, incorporado aos processos produtivos, aumenta a produtividade, o rendimento, a mais-valia, assegurando a acumulação do capital e as condições que o perpetuam, contraditoriamente neste sentido adquire força destrutiva; proporciona dominação política - quando incorporado à sociedade industrial, a modernidade e a pós-modernidade, por uma política de racionalidade científico-tecnológica assumida pelo Estado, determina condições de vida, processos de trabalho, de acesso a bens culturais como educação, saúde, seguridade; e força ideológica - quando se submete aos interesses da classe dominante, mediatizados pelo Estado e expressos em leis, planos, diretrizes governamentais e administrativos (Sobral, 1986, p. 287-305).

A ciência voltada para o desenvolvimento das tecnologias está cada vez mais deixando de lado as necessidades humanas. Disso decorrem graves consequiências, ou seja, a relação que hominiza o homo sapiens - o trabalho vem sendo destruída, precarizada, e junto a ela todos os bens construídos historicamente. É, portanto, sob essa base concreta, real, do conhecimento científico, enquanto necessidade humana vital, que enfrentamos o desafio de estudar os giros ou a virada lingüística para desmistificar as crenças e as ilusões na neutralidade científica e sua expressão atual na morte da razão.

\section{O que são os "giros" ou a "virada linguística?"}

O que são, portanto, os "Giros" ou a "virada lingüística?" São explicações científicas sobre a ciência e a produção do conhecimento científico que implicam em uma cosmovisão, em uma filosofia e estão ancorados em pressupostos ontológicos e gnosiológicos.

Segundo Ghiraldelli Júnior (2004),

A "virada linguística" ou linguistic turn é o nome adotado para um novo rumo que a filosofia ganhou no século XX. [...] Tentando explicar o 
funcionamento do aparato cognitivo e a verdade, os filósofos chegaram a dois pontos: 1) o sujeito não é uma unidade e, talvez, nem seja sujeito, talvez tenhamos de manter a noção de mente e de individualidade, mas não associála, mais, imediatamente, à noção de sujeito moderno - ou abandonamos tal noção ou a reconstruímos; 2) a mente não consegue apontar para o real e explorar o real sem a linguagem, pois esta não é apenas a expressão de pensamentos e, sim, a maquinaria do próprio pensamento e a única forma pela qual acessamos o pensamento, nosso e de outrem. Este segundo ponto é o centro da linguistic turn: os filósofos tenderam, então, a centrar atenção na linguagem, em vários sentidos. [...] Essas duas conclusões fizeram a ponte da filosofia moderna para a filosofia contemporânea $\left(2004, \mathrm{~s} / \mathrm{p}^{4}\right)$.

O giro lingüístico, segundo Sánchez Gamboa (2009-b), apresenta uma longa tradição e diversas interpretações, entretanto fundada numa mesma matriz: a reação à filosofia analítica, à lógica formal, ao mentalismo e ao primado das coisas sobre as palavras.

Ainda, o debate epistemológico contemporâneo pode ser organizado com base nos "giros", permitindo centralizar a controvérsia sobre as formas do conhecimento e do discurso científico-filosófico, reconhecendo a importância das chamadas abordagens pós-modernas e as respostas que estas vêm gerando em outras, como a hermenêutica, a pragmática, e a dialética. Ainda segundo Sánchez Gamboa (Idem), o "giro lingüístico" (linguistic turn) que se fundamenta em autores como Saussure, Barthes, Derridá, Deleuze, White e LaCapra e Foucault, sustenta, entre outras, as seguintes teses:

- A linguagem carece de toda referência à realidade (Saussure);

- Não existe nada fora do texto (Barthes);

- O texto não guarda relação com o mundo exterior, não faz referência à realidade, nem depende de seu autor. O texto também deve ser liberado do autor (Foucault);

- Não existe unidade entre a palavra e a coisa à qual se refere. Existe um infinito leque de significados sem um sentido claro (Derrida);

- No texto as intenções do autor carecem de importância (White e La Capra);

\footnotetext{
${ }^{4}$ Disponível em: http://ghiraldelli.multiply.com/journal/item/112. Acessado em: 20 de novembro de 2008, às 19:27.
} 
- A linguagem constitui em si mesma a única realidade existente, fundamentos de todos os fenômenos sociais;

- Sujeito: o homem desaparece como fator ativo e com ele a intencionalidade humana como elemento criador de significado (póshumano);

- Objeto: o texto literário, histórico, científico (em si mesmo, sem o seu referente original).

Muitas polêmicas foram levantadas a partir do "giro lingüístico", que podem ser identificadas como: "giro hermenêutico" (Gadamer) e o "giro pragmático" (Habermas), e o giro da ontologia realista.

O "giro hermenéutico", defendido por Gadamer (1995), debate as teses de Derrida e contra argumenta que "a obra, literária, artística nos diz algo atendendo a sua própria intenção"; "a palavra, a frase, o discurso nos remete ao autor e a suas intenções" (Gadamer, 1995, p. 69 apud Sánchez Gamboa, 2009-a).

Ainda segundo Sánchez Gamboa (s/d - a), Habermas e Apel propõem uma "pragmática do significado" e assumem o desafio, da defesa do realismo (giro ontológico) depois do giro pragmático, já que “[...] o giro pragmático não deixa espaço para duvidar da existência de um mundo que se percebe independente das nossas descrições e como o mesmo para todos nós". (Idem, 2009).

Sánchez Gamboa (2009 - a) demonstra ainda que além da proposição de Habermas e Apel, o giro ontológico apresenta outras três vertentes: a) “Ontologia do ser social" (Lukács e a escola de Budapeste); b) "Giro ontológico" (escola de Ilya Prigogine); e c) "Giro ontológico" (Maturana); conclui que "essa controvérsia vem se apresentando na pesquisa em Educação Física com os desafios das teorias pós-estruturalistas e pós-críticas", sendo necessário e pertinente o aprofundamento desses embates, o que nos ajuda a apontar os limites e as conseqüências dessas perspectivas epistemológicas. 


\section{O destaque para os giros na perspectiva da "ontologia realista"}

No debate sobre giros na perspectiva da ontologia realista, nos valemos novamente, da contribuição de Sánchez Gamboa (2009 - a). Segundo ele, uma das reações ao denominado "giro lingüístico" vem das teorias do conhecimento que, superando os conceitos originais do "mentalismo" (a representação dos objetos ou coisas na mente), reafirmam a necessidade de considerar a realidade (ontos) independente da consciência e da linguagem. O discurso e a linguagem deverão se referir a uma realidade (objeto) ou referente empírico, construído social e historicamente, ou mesmo virtual, mas independente do sujeito, da sua percepção, da consciência e das palavras utilizadas para se referir a ele. Segundo o autor, conforme anunciamos no item anterior são três reações, que se destacam na perspectiva da "ontologia realista": a denominada Escola de Budapeste (Luckács, Mészáros, Bhaskar), a Escola de Prigogine e a Escola de Maturana.

O que constatamos, a partir dos estudos de Sánchez Gamboa, é que o giro ontológico apresenta outras vertentes, tais como a da "Ontologia do ser social" de Lukács, defendido pela escola de Budapeste. Lukács em 1978, afirma que o reflexo, científico, estético ou literário, reflete a mesma realidade objetiva (ontológica), independente da consciência, a qual, situada na base de toda obra (literária, científica, filosófica ou estética) acentua a unidade de identidade e diversidade nas categorias tanto científicas, filosóficas e estéticas. Mészáros (1993) reafirma o método dialético que considera a existência de uma realidade (ontológica) passível de ser conhecida através de diversas mediações determinadas pelo desenvolvimento das forças produtivas e as condições materiais históricas que os sujeitos sociais se apropriam para conhecer essa realidade.

A Escola de Budapeste se apóia na teoria do conhecimento marxista. Os trechos a seguir explicitam a prioridade das condições reais do homem concreto sobre as representações, a linguagem e a interpretação: 
- São os homens que produzem suas representações, suas ideias, etc., mas, os homens reais atuantes, tais como são condicionados por um determinado desenvolvimento de suas forças produtivas e das relações que a elas correspondem;

- [...] A consciência nunca pode ser mais que o ser consciente; e o ser dos homens é o seu processo de vida real.

- [...] Não é a consciência que determina a vida, mas sim a vida que determina a consciência.

- [...] Não partimos do que os homens dizem, imaginam ou representam, tampouco não do que eles são nas palavras, no pensamento, na imaginação e na representação dos outros, para depois se chegar aos homens de carne e osso; mas, partimos dos homens em sua atividade real, é a partir de seu processo de vida real que representamos também o desenvolvimento dos reflexos e das repercussões ideológicas desse processo real (Marx \& Engels, 1981, p. 19 apud Sánchez Gamboa, 2009 - a).

Com base nessa teoria do conhecimento, Sánchez Gamboa defende que é mais apropriado denominar o "giro ontológico" de "re-virada", “inflexão ou reação ontológica”, uma vez que se pretende colocar o homem com os pés na terra e a cabeça sobre um corpo fincado na realidade.

Outra linha do "giro ontológico", segundo o autor é atribuída à escola de Ilya Prigogine (1917-2003), que busca superar os relativismos fundados na concepção subjetiva de tempo como duração (matemática quântica de Borh) ou de tempo sem direção (Einstein). A inclusão do tempo como realidade cosmológica (ontológica), além das nossas medidas (subjetivas), e a integração do "devir" (tempo irreversível) ao "ser" caracteriza uma nova perspectiva da ciência contemporânea e recoloca a ontologia como base da epistemologia. Também, Stengers, em 2002, integrante da escola de Prigogine, debate na obra Invenção das ciências modernas a tensão entre duas abordagens das ciências: a da objetividade científica das ciências exatas; e a das crenças científicas dos estudos culturais (pós-estrutralismo). A superação dessa tensão se dá através da "ontologia". A identidade da 
ciência está em discutir o que é a realidade, o que é o mundo (ser ontológico). A base da ciência está no conhecimento dos fenômenos, como eles são, como se apresentam e se revelam, e não nas formas como o homem representa ou atua sobre o mundo. O conhecimento dos fenômenos (ciência) antecede a sua intervenção sobre eles (técnica).

A terceira linha do "giro ontológico", é atribuída à Maturana em 1999, quando este pretende provar através da neurobiologia os problemas da percepção, e se depara com uma "objetividade-entreparênteses" e com a necessidade de discutir: a ontologia da explicação como condição para a constituição da observação, a ontologia da realidade, a ontologia da cognição e a ontologia do social e da ética.

Sánchez Gamboa demonstra, portanto, que nessas três linhas de pensamento, o "giro linguístico" vem gerando amplas e profundas reações, não apenas no âmbito das filosofias da linguagem, mas, também no âmbito das teorias do conhecimento fundadas no realismo (ontologia).

\section{As reações ao idealismo e ao pós-modernismo}

As contribuições que apresentamos para este debate são reações ao irracionalismo e ao pós-modernismo. Contamos para tal, com obras como a de Evangelista, em 1992, que ataca à exaustão o cerne de concepções teóricas veiculadas e cuja aceitação, à primeira vista, beira a unanimidade, e o faz ao responder, com suas investigações, às questões:

a) como o capital articula a coerção e consenso visando o controle e a dominação do trabalho;

b) como os trabalhadores, em uma resposta ativa à exploração do trabalho, encetam a sua resistência através de diversas modalidades de práxis social; e c) como a consciência apreende as contradições existentes entre capital e trabalho.

Contamos ainda, para reconhecer reações ao irracionalismo pósmoderno, com as evidentes denúncias sobre a mercantilização da sociedade 
(Betto, 2008); as imposturas intelectuais (Sokal e Bricmont, 1999); a lógica cultural do capitalismo tardio, (Jameson, 1997); о recuo da teoria, e o iluminismo às avessas (Moraes, 2003); os desvios teóricos (Anderson, 2004); de como não ler Marx de Souza Santos (Netto, 2004); a sobreposição de conceitos (Bogo, 2008); a educação contra o capital (Tonet, 2007); e por fim, a defesa do marxismo (Trotsky, $\mathrm{S} / \mathrm{D}^{5}$ ), e a atualidade extrema da concepção materialista dialética da história (Lombardi, 2003) que são algumas, e não as únicas, reações aos pós-modernismos. Estas, não de maneira hegemônica, aparecem nas 378 pesquisas defendidas na Faculdade de Educação da Unicamp (192 teses e 186 dissertações) e nas 45 pesquisas dedicadas à problemática da Educação Física.

Diante da extensa reação aos "pós-modernirmos", foi necessário fazermos opções de exposição no presente texto. Inicialmente, nos valemos de uma crônica de Betto $(2008)^{6}$ para descrever o que é mesmo pósmoderno? Somos todos pós-modernos?

[...] nenhum sistema filosófico resiste, hoje, à mercantilização da sociedade: a arte virou moda; a moda, improviso; o improviso, esperteza. As transgressões já não são exceções, e sim regras. O avanço da tecnologia, da informatização, da robótica, a gloogletização da cultura, a telecelularização das relações humanas, a banalização da violência, são fatores que nos mergulham em atitudes e formas de pensar pessimistas e provocadoras, anárquicas e conservadoras. Na pós-modernidade, o sistemático cede lugar ao fragmentário, o homogêneo ao plural, a teoria ao experimental. A razão delira, fantasia-se de cínica, baila ao ritmo dos jogos de linguagem. Nesse mar revolto, muitos se apegam às "irracionalidades" do passado, à religiosidade sem teologia, à xenofobia, ao consumismo desenfreado, às emoções sem perspectivas. Para os pós-modernos a história findou, o lazer se reduz ao hedonismo, a filosofia a um conjunto de perguntas sem respostas. $\mathrm{O}$ que importa é a novidade. Já não se percebe a distinção entre urgente e importante, acidental e essencial, valores e oportunidades, efêmero e permanente. A estética se faz esteticismo; importa o adorno, a moldura, e não a profundidade ou o conteúdo. O pós-moderno é refém da exteriorização e dos estereótipos. Para ele, o agora é mais importante que o depois. Para o pós-moderno, a razão vira racionalização, já não há pensamento crítico; ele prefere, neste mundo conflitivo, ser espectador e não protagonista, observador e não participante, público e não ator. O pós-moderno duvida de

\footnotetext{
${ }^{5}$ Primeira Edição: Leon Trotsky, In Defense of Marxism, New York 1942. Disponível em: http://www.marxists.org/portugues/trotsky/ano/defesa/index.htm 6Disponível em:

http://www.correiocidadania.com.br/index2.php?option=com content\&do_pdf=1\&id=2314 . Acessado em: 21 de novembro de 2008, às 20:27.
} 
tudo. É cartesianamente ortodoxo. Por isso não crê em algo ou em alguém. Distancia-se da razão crítica criticando-a. Como a serpente Uroboros, ele morde a própria cauda. E se refugia no individualismo narcísico. Basta-se a si mesmo, indiferente à dimensão social da existência. $\mathrm{O}$ pós-moderno tudo desconstrói. Seus postulados são ambíguos, desprovidos de raízes, invertebrados, sensitivos e apáticos. Ao jornalismo, prefere o shownalismo. O discurso pós-moderno é labiríntico, descarta paradigmas e grandes narrativas, e em sua bagagem cultural coloca no mesmo patamar Portinari e Felipe Massa; Guimarães Rosa e Paulo Coelho; Chico Buarque e Zeca Pagodinho. O pós-modernismo não tem memória, abomina o ritual, o litúrgico, o mistério. Como considera toda paixão inútil, nem ri nem chora. Não há amor, há empatias. Sua visão de mundo deriva de cada subjetividade. A ética da pós-modernidade detesta princípios universais. É a ética de ocasião, oportunidade, conveniência. Camaleônica, adapta-se a cada situação. A pós-modernidade transforma a realidade em ficção e nos remete à caverna de Platão, onde nossas sombras têm mais importância que o nosso ser e as nossas imagens que a existência real.

Á pergunta inicial, ele responde que sim, se comungamos essa angústia, essa frustração frente aos sonhos idílicos da modernidade.

Segundo Anderson (1999), a primeira abordagem filosófica do termo pós-modernidade foi realizada por Lyotard em seu livro "A condição pósmoderna", datado de 1979. Nele o autor utiliza o conceito de "jogos de linguagem", originalmente desenvolvido por Ludwig Witgenstein, e referese a uma agonística entre esses jogos - característica da experiência da pósmodernidade, assim como a fragmentação e multiplicação de centros e a complexidade das relações sociais dos sujeitos.

Lyotard (1979) considera que a chegada da pós-modernidade ligava-se ao surgimento a uma sociedade pós-industrial, na qual o conhecimento tornara-se a principal força econômica de produção, embora perdendo a sua legitimidade tradicional porque atrelado ao capital, ao estado, sendo a verdade reduzida ao desempenho à eficácia. A Ciência tornara-se um jogo de linguagem que já não podia mais reivindicar o privilégio sobre outras formas de conhecimento visto ter ocultado sua base, a saber, as duas grandes narrativas da modernidade: a primeira herdada da Revolução Francesa, materialista, que colocava a humanidade como agente histórico de sua própria libertação por meio do avanço do conhecimento e, a segunda, descendente do idealismo alemão que via o espírito como progressiva revelação da verdade, mitos que justificaram a modernidade. 
Segundo Santos (2006), convencionou-se que o modernismo teria chegado ao fim na década de 40, mas especificamente no dia 6 de agosto de 1945, às 8 horas e 15 minutos, quando a bomba atômica foi lançada sobre Hiroxima, iniciando o pós-modernismo, visível na tecnologia eletrônica que invadiu o cotidiano, na era da informática; na avidez de consumo, na sedução do individuo, na moral hedonista, com os valores colocados no prazer, expressando-se na arquitetura, na pintura, na escultura. Os signos e códigos representam a realidade. É o quarto poder e existem ciências para estudá-los Semiologia (ciência dos signos) e a Teoria da Comunicação. O modelo de signo criado pelos semiólogos ingleses Ogdon e Richards, segundo Santos (2006), explica que o ponto central do pós-modernismo tem a ver com a Linguística, a Cibernética, a Estética e até a Filosofia. É um tripé que tem em um de seus ápices o Signo, a Linguagem, o Simulacro, o Espetáculo (pósmodernismo), de outro o Espírito, a razão, a idéia, o sujeito a referência. Por fim no terceiro ápice o referente, o objeto, a realidade, a matéria. A pósmodernidade é um mundo super criado pelos signos. Matéria e espírito se esfumam em imagens, em dígitos, num fluxo acelerado. A isso, os filósofos denominam de desreferencialização do real e dessubstancialização do sujeito, ou seja, a realidade se degrada em fantasmagoria e o sujeito (indivíduo) perde a substancia interior, sente-se vazio (Santos, 2006, p. 16). O filho do modernismo diz Santos, mobilizava as massas para a luta política. Na sociedade pós-industrial dedica-se às minorias, atuando na micrologia do cotidiano. O pós-modernismo é um ecletismo, isso é, a mistura de várias tendências. Prevalece o circuito informação-estetização-erotizaçãopersonalização do cotidiano. Só há revolução no cotidiano. Enfim o pósmodernismo encarna estilos de vida, filosofia na qual viceja a idéia niilista do nada, do vazio, da ausência de valores e sentidos para a vida. Afirma Santos (2006, p. 11), o pós-modernismo é coisa típica das sociedades pós-industriais baseadas na informação. Paira, portanto, um irracionalismo próprio do modo do capital determinar, em última instância, os rumos da economia.

Para Eagleton (1998), que realiza críticas contundentes à força do pósmodernismo e aos seus equívocos, o pós-modernismo refere-se em geral a 
uma forma de cultura contemporânea e o termo pós-modernidade alude a um período histórico especifico. Pós-Modernidade segundo o autor é uma linha de pensamento que questiona as noções clássicas de verdade, razão, identidade e objetividade, a idéia de progresso ou emancipação universal, os sistemas únicos, as grandes narrativas ou os fundamentos definitivos da explicação. Vê o mundo como contingente, gratuito, diverso, instável, imprevisível. Emerge de uma nova forma do capitalismo. Para Mészaros (2003) o que emerge do sociometabolismo do capital é a barbárie. É taxativo quanto ao que nos espera para o próximo período de recomposição hegemônica do modo do capital organizar a produção dos bens materiais e imateriais - é a barbárie se as forças socialistas não avançarem.

Para demonstrar as falácias e o simulacro da pós-modernidade forjada por imposturas intelectuais podemos apontar a sangrenta e cruel batalha travada, por exemplo, na América Latina contra a violência dos países colonialistas e imperialistas, que durante séculos vem oprimindo os povos com um padrão de relações que se caracterizam, segundo Florestan Fernandes, como de exploração e explotação dos seres humanos e da natureza. Salazar (2006) nos apresenta dados históricos sobre a violência que caracterizam bem um processo de revolução permanente (Trotsky, 1995), que coloca por terra a tese pós-modernista de que a revolução se dá somente no cotidiano. O esquema por ele abordado demonstra com dados concretos o período da colonização, da independência parcial das nações e dos países, a era da industrialização, das políticas neo-liberais, de seu esgotamento e agora, da busca dos povos latino americanos pela soberania das nações. A revolução está em curso, para superar a fase pré-histórica da relações sociais possíveis à humanidade (Marx, 1986), e aponta para uma formação econômica, um modo de organizar a produção e reprodução da vida qualitativamente superior. O pós-moderno ou a contemporaneidade não é uma forma de superação do moderno, segundo Freitas (2005), mas, sim o aprofundamento, sob outras bases, das formas de exploração do homem.

Salazar (2006) expôs que a América Latina não deixou de lutar um dia sequer na busca de completar o ciclo das revoluções em curso, datadas 
desde a primeira revolução reconhecida na América Latina, a Revolução Haitiana de 1804 que seguiu no rastro das revoluções em curso na Europa, onde as bandeiras da Igualdade, Liberdade, Fraternidade estavam erguidas. Primeira republica a libertar os escravos o Haiti hoje luta para retirar de seu solo tropas de ocupação imperialista, lideradas, lamentavelmente, pelo Brasil. Entre brutais repressões militares até a atua manifestação continental contra o imperialismo norte-americano, em defesa da soberania das nações, lutam os povos. Por mais que nos seja difícil reconhecer a revolução e permanente, esta práxis social que eleva sim a consciência de classe dos trabalhadores, se não de maneira célere e linear, como seria necessária, mas, sim, por contradições, idas e voltas, refluxos e avanços significa as formas de resistência da classe trabalhadora, muitas vezes derrubada, freada, assegurada, por formas de governança e políticas compensatórias, focais, assistencialistas. Neste lastro histórico asseguram-se, forjam-se, elaboram-se teorias, explicações cientificas sobre a natureza, o homem, a sociedade e o conhecimento. Wood e Foster (1999, p. 7 e p.196) ao investigarem sobre a agenda "pós-moderna" e defenderem a história demonstram as pretensões dos pós-modernistas com suas concepções sobre o conhecimento cientifico e seu relativismo e solipsismo ${ }^{7}$. O fio principal que perpassa os princípios pós-modernos é a ênfase na natureza fragmentada do mundo e do conhecimento. As implicações políticas disso tudo é que não existe base para solidariedade e ação coletiva fundamentada nos interesses dos produtores livremente associados. É, portanto, neste movimento onde se expressam a luta de classes que é possível reconhecer a que servem certas teorias? O que significa decretar o marxismo como morto? O que são os giros? Por que negar a capacidade do ser humano compreender e agir no real para transformá-lo com radicalidade. Assim como os trabalhadores

\footnotetext{
7 O solipsismo é a consequência extrema de se acreditar que o conhecimento deve estar fundado em estados de experiência interiores e pessoais, não se conseguindo estabelecer uma relação direta entre esses estados e o conhecimento científico objetivo de algo para além deles. O solipsismo do momento presente estende este ceticismo aos nossos próprios estados passados, de tal modo que tudo o que resta é o eu presente. Disponível em: http://pt.wikipedia.org/wiki/Solipsismo. Acessado em: 20 de novembro de 2008 às 21:19.
} 
reagem e resistem às forças que os oprimem na formação econômica em geral, são esboçadas as resistências e reações aos desvios teóricos, enfim ao pós-modernismo.

As reações ao pós-modernismo aparecem tanto na crônica de Betto (2008), quanto na produção acadêmica e em outros espaços da vida. As reações ao pós-modernismo, que se infiltram, com suas explicações, posições e posturas, em todos os âmbitos da vida humana e do Estado, não aparecem somente no campo da produção do conhecimento científico, no embate entre o idealismo e o materialismo. Aparecem também nos enfrentamentos para além do debate na academia e se expressam no interior dos partidos políticos, quando está em jogo a direção do projeto histórico em disputa, quando estão em confronto as reformas e as contra-reformas, a revolução e a contra-revolução (Netto, 2004). Nos movimentos de luta social contra o capital, quando está em jogo o papel e as relações a serem estabelecidas entre o público e o privado, entre o Estado burguês e o rumo que devem assumir as políticas públicas, por exemplo, a formação humana alienação X emancipação humana. Presentes na luta dos contrários e no enfrentamento da grande contradição do capital educar/alienar. Aparece na luta pela definição de políticas públicas no campo do esporte entre o projeto para elevar o padrão cultural esportivo da população brasileira e o projeto de transformar o Brasil em um país Olímpico. Aparece no âmbito sindical quando está em confronto o papel a ser assumido pelas direções na luta de classes e, fundamentalmente, nas nossas vidas cotidianas, em nossas famílias, quando temos que nos situar perante a história e nos reconhecermos enquanto gênero humano, enquanto humanidade, que necessita se emancipar, que está em franco processo de degeneração e destruição e que deve encontrar outro modo de organizar a produção e reprodução da vida qualitativamente superior. Aparece no enfrentamento ao plano mundial de educação sustentado pelas formulações encontradas em Relatórios de agentes internacionais como a UNESCO que preconiza, conforme podemos constatar no relatório da comissão internacional da Organização das Nações Unidas para a Educação, a Ciência e a Cultura 
(UNESCO), conhecido como Relatório Jacques Delors (1998), nome do presidente da Comissão, como pilares para a educação o "aprender a aprender", "aprender a ser", "aprender a fazer", "aprender a conviver", etc. Duarte (2003) refere-se a 4 pilares, 7 saberes e 10 competências.

A reação pode ser verificada no contra-ponto a isso tudo quando se levantam sólidas proposições pedagógicas nas lutas dos movimentos que enfrentam os pilares mais gerais do capital, a saber, a propriedade privada dos meios de produção, a super-exploração do trabalho assalariado e articulam-se as lutas imediatas com as mediatas e históricas, quando se defende para a formação escolar uma consistente base teórica materialista dialética histórica, a consciência de classe forjada na inserção concreta na luta de classes, a formação política na defesa da classe trabalhadora e a organização revolucionária, como pilares centrais do projeto de escolarização. Também pode ser verificada quando defende-se como fundamentos da educação, a escola do trabalho socialmente útil como principio educativo, o sistema de complexos temáticos para organizar o conhecimento no programa escolar e, a auto-organização dos sujeitos, elementos centrais para a escolarização da população de uma nação que se quer soberana, digna e com seu povo feliz, conforme localizamos em proposições para a Educação do Campo do MST - Movimento dos Trabalhadores Rurais Sem Terra.

A batalha de enfrentamento do pós-modernismo e sua definição de padrões de ciência, crítica social e de prática política não tem sido nada fácil. Trata-se de enfrentar a "lógica cultural" do capitalismo (Jameson, 1997). O combate é diuturno e pode ser verificado, por exemplo, na obra de Alan Sokal e Jean Bricmont (1999), que vem denunciando o relativismo pós-moderno, que sustenta a tese de que a verdade objetiva não passa de uma convenção social. São analisados textos que demonstram as mistificações físico-matemáticas perpetradas por Lacan, Kristeva, Irigaray, Latour, Baudrillard, Deleuze, Guatteri, Virilio. Eles demonstram que "o rei está nu", demonstram o abuso da terminologia científica e a irresponsável extrapolação de idéias das ciências naturais para as ciências sociais. 
Duarte (2003), para quebrar a ilusão pós-moderna da "sociedade do conhecimento" ressalta que não pactua com o fetichismo de que vivemos na "sociedade do conhecimento", das "tecnologias de informação e de comunicação (TICs)", nem com a idéia de que o conhecimento, por si só, será capaz de, em todas as esferas da vida social contemporânea, rearticular experiências sociais possibilitando novas formas de interação social e transformando as normas e os valores. Não pactua com o fetiche da "ética" que oculta, nega e desconsidera a luta de classes e ignora o movimento mais geral do capital, suas leis e sua estrutura e organiza o poder da burguesia através do Estado definindo os rumos da economia política. Ressalta que assim como no século $\mathrm{XX}$ tivemos os avanços decorrentes de descobertas nas ciências básicas do século XIX, nas áreas de ciências naturais e exatas, visíveis em tecnologias aplicadas que possibilitaram entre outros fatos a chegada a outros planetas, o século XXI deverá avançar a partir das descobertas básicas dos séculos XIX e XX nas áreas das ciências biológicas e humanas.

O que constatamos, tanto na literatura consultada, bem como, na análise das bases teóricas da política educacional no Brasil, é o evidente e progressivo recuo da teoria em pesquisas educacionais, um processo que traz implicações epistemológicas, éticas e políticas, segundo Moraes (2003) na própria produção de conhecimentos na área. Ainda, segundo o autor, as possíveis determinações desse processo são: a) a emergência de um ethos neodarwinista nas universidades, com a consequente degradação da vida acadêmica e, b) por outro lado, o ceticismo epistemológico corrente que trivializa a questão do conhecimento e da verdade e procede a um sutil exercício linguístico criando um novo e pragmático vocabulário destinado a assegurar a obediência e a resignação públicas. Ao tratar do recuo da teoria Moraes (2003, p. 151) parte da consideração dos efeitos desestabilizadores da reestruturação socioeconômica em escala planetária. Parte dos espraiamento dos imperativos capitalistas em todas as esferas da vida humana estado de coisa que tem efeitos profundos sobre as várias práticas sociais, de modo particular, na educação. A isso corresponde uma educação, 
dos "pactos prontos", aprendizagens configurada nos discursos políticos educacionais como verdadeira panacéia. A discussão teórica, afirma Moraes (2003, p. 153), tem sido "gradativamente suprimida ou relegada a segundo plano nas pesquisas educacionais, com implicações que podem repercutir, a curto e médio prazo, na própria produção do conhecimento da área.” E o fim da teoria acompanhada da promessa de uma utopia educacional alimentada por um indigesto pragmatismo, uma utopia praticista. Uma verdadeira “marcha à ré intelectual”. Segundo o referido autor, o que está direcionando o movimento que marginaliza o debate teórico é a efetivação das próprias políticas educacionais em nível nacional e internacional, por exemplo, as exigências das agencias financiadoras, a CAPES, e outras.

Outra razão é que no plano teorético as propostas que desqualificam a teoria têm origem na convicção da falência de uma determinada concepção de razão: a chamada razão moderna de corte iluminista. Uma vez perdidos os tradicionais instrumentos de legitimação instaura-se o mal estar epistemológico, o cetisismo, ético, político e, o desencanto, abrindo-se a agenda que abrigou os "pós", os "neo", os "anti" que infestam a intelectualidade. Inaugura-se a era cética e pragmática. A negação da objetividade aparece associada à ideia de desintegração do espaço público, do fetichismo da diversidade, da compreensão de que o poder e a opressão estão pulverizados em todos os lugares. Daí a impossibilidade de uma base de resistência e de enfrentamento da realidade. Frente a ela o sujeito estético, fragmentário reconhece, mas revela-se impotente. Nessa inflexão teórica o sutil exercício linguístico põe em pratica a pragmática retórica de ressignificação de conceitos. Alcançar o consenso é o fundamental, substituir sentidos e significados e a precisão de conceitos por termos vagos que diluem principalmente seu caráter rigoroso. São exemplos, a substituição dos termos como "luta de classes" por "identidade", a ressignificação de "sociedade civil", sujeitos histórico por atores, condições objetivas da existência (formações econômicas) por cenários, etc. Negam-se articulações, nexos determinações entre economia e poder político, proclama-se a autonomia do político e do discurso. No horizonte ideológico 
apaziguado constrange-se o agir consciente, diluem-se valores e fins, esvaziam-se diferenças, reduz-se tudo a diversidade cultural. Denotam-se conforme Moraes (2003), o silêncio e o esquecimento.

Netto (2004) em seu livro "Marxismo Impenitente" discute as idéias marxistas e ressalta que para "purgar-se do desastre em que se saldou a experiência do chamado "socialismo real", pretendem superar a "ortodoxia metodológica", pela via do pluralismo, transitar a modernidade do socialismo científico pra a criatividade pós-moderna da reinvenção das utopias, substituir as exigências da supressão da propriedade privada dos meios fundamentais de produção e controle social do mercado, deslocar as velhas concepções das lutas de classes pelas "novas" lutas sociais moleculares, enfim, propor, em lugar do "ultrapassado" projeto revolucionário, a constituição de um novo contrato social. Trata-se da capitulação intelectual que tem contribuído para as derrotas que a classe trabalhadora vem amargando. Faz-se necessário a quebra do cerco ideológico, com a descoberta dos "clássicos" da tradição marxista.

O autor reage também à leitura "simplória" e incompetente de Boaventura de Souza Santos sobre a obra de Marx e sua contribuição para a sociologia; critica a "sinopse crítica do desenvolvimento do marxismo, do final do século XIX à década de 80 do século XX, organizada em quatro períodos com tratamento bem diferenciado", pelo seu caráter tosco e insuficiente que culmina com conclusões reducionistas e com o desprezo as reiteradas e enfáticas notações marxianas sobre o caráter tendencial e histórico das leis histórico-sociais. Souza Santos, a partir de sua "avaliação do marxismo enquanto tradição teórica da sociologia" admite que, para o enfrentamento da "transição paradigmática" Marx não tem serventia. As determinações complexas, bem como os complexos sistemas de mediações, que articulam a totalidade concreta que é a sociedade burguesa são neglicenciadas nas análises, admitindo-se assim, pós-modernismos, que não suportam o rigor da teoria marxista.

Bogo (2008), em seu livro "Identidade e luta de classes", critica os pós-modernos que "induzidos pelo processo de individualização humana", 
cada vez mais crescente no capitalismo, apegam-se aos conceitos de identidade com a clara intenção de colocá-lo em destaque, sobrepondo-o ao conceito de luta de classes. E esta erosão do conceito e das referencias afeta profundamente as possibilidades de avançar em direção a emancipação humana. Defende as leis da dialética materialista histórica para ultrapassar as limitações das identidades e para compreender as contradições do capital, expressas no Estado-nação, na capacidade de percepção das diferenças, na perda dos direitos, na exaustão da natureza e o extermínio das espécies.

Para Kurz ${ }^{8}$ (2002), sociólogo alemão, autor de "Razão Sangrenta", aponta que a pós-modernidade está no fim. De qualquer modo, o conceito foi desde sempre um embrulho enganador: deveria sugerir algo historicamente novo e, no entanto, não podia indicar um conteúdo próprio. A vacuidade das autodenominações remete ao fato de a pós-modernidade não ser nada senão o capitalismo moderno em estado de carência conceitual e em uma forma tardia de auto-espelhamento fútil.

Para Evangelista (1992) certos setores intelectuais das Ciências Sociais afirmam que atravessamos uma crise teórica sem precedentes em toda a história e estamos diante de uma verdadeira crise "de paradigma". Dentro dessa crise das grandes teorias sociais estaria situada a crise do marxismo. A critica recai sobre o marxismo e a necessidade de um novo paradigma capaz de dar visibilidade a "novos fenômenos", "novas dimensões da realidade", "novos atores", "novos movimentos sociais", "novos espaços políticos”, "novas práticas sociais", "novas representações simbólicas" e a uma "nova teorização social".

Os inspiradores, ou seja, os fundamentos teóricos da critica ao marxismo vem de Castoriadis e se expressam na obra de Sader (1987). Em síntese, para estes autores "o marxismo não é mais a expressão do caráter revolucionário do proletariado ou quaisquer camadas sociais" (Evangelista, 1992, p. 18).

Outro vinculo identificado por Evangelista vêm do pós-estruturalismo

\footnotetext{
${ }^{8}$ Disponível em: http://obeco.planetaclix.pt/rkurz103.htm. Acessado em: 20 de novembro de 2008, 22:15.
} 
francês, principalmente sua vertente Foucaultiana.

O estruturalismo e o pós-estruturalismo podem ser situados como integrantes de um diversificado movimento intelectual de critica à modernidade e à razão moderna. É a "apologia orgiástica ao sem-sentido e da desrazão" segundo Zaidam Filho, (1989, p. 25). Para Evangelista

Se, é impossível a descoberta de um sentido no processo histórico-social, que posa ser racionalmente apreendido, instaura-se o império da incognoscibilidade com a relativização de todo o conhecimento, permitindo uma multiplicidade inesgotável de interpretações, todas válidas. A realidade teria como característica essencial o seu caráter fragmentário, que impede qualquer possibilidade de síntese ou totalização, que apreenda o real. É daí que advém o jogo da crítica ao marxismo (Ibdem, p. 31).

Para Evangelista, estas teorias estruturalistas e pós-estruturalistas levam a desvios teóricos que enfraquecem a práxis social de resistência, a elevação da consciência de classe.

Para consubstanciar a crítica no campo da educação e dar-lhe consistência vou me valer de uma resenha do livro do professor Luís Carlos de Freitas $(2005)^{9}$. O autor expõe elementos que justificam seu interesse em discutir a temática, que passam por dar visibilidade a um contraponto às consequiências da virada do capitalismo em direção à globalização e, a partir daí, a organização do movimento pós-modernista, que resultaram em dois impactos de alto poder destrutivo no campo da educação: 1) o impacto das políticas neoliberais; e 2) e, somado ao primeiro (predominantemente no campo da economia e das políticas públicas), o impacto das teses pósmodernistas no campo da ciência e da cultura. Para o autor, "prestam um serviço inestimável à causa liberal-conservadora, à medida que deixam o campo econômico e político inteiramente à mercê da interpretação neoliberal, sem falar do seu impacto negativo na mobilização social", porque para os pós-modernos, a organização se dá pelo dissenso, pois os consensos restringem e oprimem. (Freitas, 2005, p.13-16).

9 FREITAS, Luiz Carlos de. Uma pós-modernidade de libertação: reconstruindo as esperanças. Campinas-SP: Autores Associados, 2005. Resenha elaborada por Joelma Albuquerque, doutoranda da FE/UNICAMP, e bolsista do projeto Educação do Campo do Grupo LEPEL/FACED/UFBA. 


\section{Os desvios teóricos e o atraso da teoria e da política}

Perry Anderson, em seu livro Considerações sobre o marxismo ocidental, apresenta, entre as principais características do marxismo ocidental as seguintes: a) o divórcio estrutural do marxismo com a prática política, da teoria com a práxis; b) o silencio premeditado do marxismo ocidental em áreas fundamentais para as tradições clássicas do materialismo histórico: as leis econômicas do funcionamento do capitalismo como um modo de produção, a análise da máquina política do estado burguês, a estratégia da luta de classes necessária para derrubá-la; c) deslocamento do eixo gravitacional do marxismo europeu no sentido da filosofia, de estudos da superestrutura, com sua conseqüente "academização". Para Anderson, ajustar as contas com esta tradição, isto é, conhecê-la e romper com ela, é assim um dos pré-requisitos para uma renovação da teoria marxista hoje." (Pucci,1995, p. 13).

Com base na sistematização aqui exposta sobre os giros, as viradas, o pós-modernismo e as reações a ele, podemos nos perguntar sobre teorias educacionais e pedagógicas que prevalecem no Brasil. Qual a nova pedagogia da hegemonia? Quais as estratégias do capital para educar o consenso? (Neves, 2005). Quais os giros da teoria? Como penetram, com que argumento, na organização do trabalho do professor na sala de aula e na escola? Como sustentam políticas educacionais de estado e de Governos? Para exemplificar, vamos mencionar seis nomes que ganharam especial destaque no Brasil e que compõe a hegemonia no campo teórico educacional: o francês Edgar Morin, o suíço Philippe Perrenoud, os espanhóis César Coll e Fernando Hernández, o português António Nóvoa e o colombiano Bernardo Toro. O que defendem esses teóricos? São "autores de sucesso" porque vendem muitos livros, são citados e elegidos como suporte teórico de teses e dissertações. Seu prestígio reside, em boa parte, nos livros publicados sobre temas pontuais e na influência nas políticas públicas educacionais no Brasil. Diferentemente dos grandes nomes da educação, como Vigotsky, Jean Piaget, Paulo Freire ou Emilia Ferreiro, esses autores de vanguarda não têm a pretensão de fazer descobertas geniais. O "negócio" deles é reprocessar idéias já largamente difundidas (e aceitas) e apresentá-las numa linguagem fácil, objetiva e coerente com as necessidades atuais - diz a imprensa que os divulga. Coll, por exemplo, partiu das idéias de Piaget para escrever sobre currículo. Perrenoud 
desenvolveu o conceito de competências - que o tornou um fenômeno editorial - depois de estudar, entre outros, os ensinamentos de Freire. Toro ganhou fama ao definir as sete bases sobre as quais todo estudante deve construir não só o aprendizado, mas a vida. Morin, o mais idoso, vem há algumas décadas aprimorando a chamada teoria da complexidade e influenciou a política educacional do Brasil com sua teoria dos sete saberes. Morin escreve o livro Os sete saberes necessários à educação do futuro (2001), apresentando o que ele mesmo chama de inspirações para o educador e que é comumente chamado de " Os 7 saberes", onde se refere aos saberes necessários para uma boa prática educacional $: 1^{\circ}$ Saber: Erro e ilusão - Não afastar o erro do processo de aprendizagem, íntegrar o erro ao processo, para que o conhecimento avance; $2^{\circ}$ Saber: $\mathrm{O}$ conhecimento pertinente. Juntar as mais variadas áreas de conhecimento, contra a fragmentação; $3^{\circ}$ Saber: Ensinar a condição humana. Não somos um algo só. Somos indivíduos mais que culturais, somos psíquicos, físicos, míticos, biológicos, etc.; $4^{\circ}$ Saber: Identidade terrena. Saber que a Terra é um pequeno planeta, que precisa ser sustentado a qualquer custo. Idéia da sustentabilidade terra-pátria. $5^{\circ}$ Saber: Enfrentar as incertezas. Princípio da incerteza. Ensinar que a ciência deve trabalhar com a idéia de que existem coisas incertas; $6^{\circ}$ Saber: Ensinar à compreensão. A comunicação humana deve ser voltada para a compreensão. Introduzir a compreensão; compreensão entre departamentos de uma escola, entre alunos e professores, etc.. $7^{\circ}$ Saber: Ética do gênero humano. É a antropo-ética. Não desejar para os outros, aquilo que não quer para você. A antropo-ética está ancorada em três elementos: Indivíduo; Sociedade; Espécie. Edgar Morin influenciou também nas medidas para a reforma universitária no Brasil no inicio do Governo Lula, através de sua ONG (OUROS). O português Nóvoa, dedicase a formação profissional e defende a formação do professor reflexivo. $\mathrm{O}$ espanhol Hernández mesclou várias teorias para difundir os benefícios de se trabalhar com projetos didáticos. "Eles têm enorme capacidade de síntese", diz Sérgio Antonio da Silva Leite, pesquisador da Universidade Estadual de Campinas (Unicamp). "E têm também o mérito de expor suas idéias no 
momento de redefinição do papel da escola", completa Ana Rosa Abreu, consultora do Ministério da Educação. Conhecer esses seis autores é fundamental, diz a imprensa, para manter-se atualizado e, sobretudo, refletir sobre os problemas de sala de aula. "Não espere encontrar, nos livros, soluções prontas para o dia-a-dia. Elas só surgem com uma interpretação da leitura apoiada na experiência pessoal", explica Ana Rosa. A professora Luciola Licínio de Castro Paixão Santos, doutora em Formação de Professores pela Universidade Federal de Minas Gerais (UFMG), destaca outra característica comum aos novos pensadores: textos de fácil compreensão. "Talvez esse seja um dos motivos para o enorme sucesso deles no Brasil." A imprensa estimula os professores a buscarem as inovações didáticas. Dizem, “Agora é a sua vez. Afinal, como você já cansou de ouvir, as novidades tecnológicas surgem a toda hora, o mercado de trabalho anda exigente (com os professores e com os alunos), a sociedade reavalia seus valores dia após dia, então é imperativo aperfeiçoar a didática”. Asseguram que, conhecendo as propostas de Morin, Coll, Hernández, Perrenoud, Nóvoa e Toro, o professor estaria mais preparado para superar o desafio das inovações didáticas. Nada de critica, nada de localização dessa tendência teórica com o avanço do neo-tecnicismo. Por isso, é vital, é imprescindível, ajustar as contas com tal tradição, que perde a referência teleológica, histórica, não se sustenta com consistência e aderência a prática concreta nas escolas brasileiras e se apresenta a-crítica e a-histórica.

Neves (2005) organizou o resultado de três anos de pesquisa do Coletivo de Estudos de Política Educacional da Universidade Federal Fluminense (UFF) e demonstrou como o Estado brasileiro vem difundindo, na sociedade brasileira, novos ideais, idéias e práticas voltadas para a construção de uma nova pedagogia da hegemonia: uma educação para o consenso dos sentidos de democracia, cidadania, ética e participação adequados aos interesses privados do capital. Demonstra como a nova pedagogia atua no sentido de restringir o nível de consciência política coletiva dos organismos da classe trabalhadora que ainda atuam no nível 
ético-politico para o nível econômico corporativo. A Nova hegemonia estimula a pequena política em detrimento da grande política proporcionando a grande política da conservação. Apresenta elementos sobre o Estado educador que através de novas estratégias nas relações entre o Estado e a sociedade civil consolida e aprofunda, no espaço brasileiro, o projeto neoliberal de sociabilidade, o projeto da burguesia mundial para a atualidade - a Terceira Via, com uma nova interpretação do mundo, uma nova ideologia, sintonizando o "novo estado democrático" com os organismos da sociedade civil, ou seja, a articulação entre a esfera estatal e a esfera privada, incorporando e superando a concepção de individualismo do pensamento (neo)liberal. Esta concepção, segundo Lima e Martins, (2005, p. 42-67) tem como objetivo prático: a) construir consciência política que não permita ao individuo compreender seu real papel sócio-político a partir de sua posição nas relações de produção; b) induzir a percepção de que seus valores são decorrentes de sua capacidade de se autogovernar e que metas e objetivos são independentes das condições concretas; c) estimular possibilidades de associações para participação em processo isolados sem que isto signifique incentivar a consciência política de pertencer a uma dada classe social que não detém meios de produção e que é super explorada. Segundo Melo (2004, p. 69-82) isto constitui tática de uma frente de defesa dos interesses sociais do capitalismo mundial representada nos organismos internacionais de condução de um novo bloco histórico. Essas mudanças se materializam na inserção da ciência e tecnologia na produção social, na reprodução ampliada do capital e do trabalho, bem como no delineamento das transformações nas relações de poder do Estado. Harmonia social e realização intensa de estratégias de conformação social são importantes nesta governança mundial do capital. Para isso é preciso educar/deseducar a classe trabalhadora. Não é portanto, pouca coisa nos perguntarmos como é tratado no interior da escola a teoria do conhecimento que contribua não para a acomodação e harmonia no capitalismo, mas, sim, para revolucionar o modo de produção e reprodução da vida na perspectiva teleológica da superação do capital rumo ao projeto histórico socialista? 
Não são hegemônicas na atualidade, proposições superadoras. Esse ciclo encerrou-se na década de 80 inicio dos anos 90. Provavelmente esse atraso e os desvios decorrem da prevalência no Brasil e na América Latina, de teorias reacionárias, anti-revolucionárias, que mantêm a internalização da alienação humana (Mészáros 2005). Levantamos a hipótese de que estas teorias podem ser reconhecidas como reacionárias e anti-revolucionárias, também, pelos seguinte:

a) separam a teoria da prática política, as premissas teóricas das premissas programáticas - Trotsky (1995); Lessa (2007); Coggiola (1996); Lombardi e Saviani (2005).

b) se valem da práxis utilitária em detrimento da práxis revolucionária Kosik (1976); Kopnin (1972); Cheptulin (1982).

c) deslocam o eixo gravitacional da filosofia materialista dialética para "giros" idealistas, que subsidiam estudos da superestrutura, com a conseqüente "academização" e a fixação de intelectuais institucionais em retirada, que enfatizam abordagens individualistas e idealistas - Anderson (1989), Petras (2002); Duarte (2001; 2003; 2004).

d) adesão acrítica ao projeto de mundialização da educação subsidiado pelo liberalismo, por teorias pós-modernas e financiado pelas agências multilaterais de investimento - Petras (2002, 1996a, 1996b); Tommasi; Warde; e Haddad (1996); Leher (2001); Melo (2004); Lombardi e Sanfelice (2007).

e) total ou parcial abandono do materialismo dialético e histórico como lógica e teoria do conhecimento para orientar o currículo e o não enfrentamento dos limites apontados pela crítica - Frigotto (1996, 1998); Kuenzer (1998); Duarte (2003).

f) silêncio da teoria sobre: - as leis econômicas do funcionamento do capitalismo como um modo de produção da vida - Marx (1983) e Engels (1990) em franca decomposição, degeneração, destruição; - da máquina política do estado burguês - Lênin (2007a; 2007b) e; - da estratégia da luta de classes necessária para derrubá-la (Trotsky, 1995).

g) a dissociação entre história e teleologia - Lombardi e Saviani (2005). 
Diante deste quadro, é necessário conhecer como o marxismo ocidental chega ao Brasil, em que contexto ele se desenvolve e o que representou o confronto e os embates com as influências e adesões ao liberalismo e ao neoliberalismo da "nova esquerda", especialmente no Partido dos Trabalhadores, mas não só. No interior de todos os âmbitos da vida, da academia dos movimentos sindicais, estudantil e populares, favoreceu-se um desprezo pela elaboração teórica o que acabou refletindo na prática e nas novas temáticas, cada vez mais diluídas, dispersas e sem assegurar a totalidade, o conjunto e a radicalidade nas elaborações, logo, não é propositivo, na linha da superação dos limites teóricos e, muito menos, do projeto histórico.

Com base no presente instrumental, podemos agora nos debruçar na produção cientifica que circula no campo da educação e da educação física, seja em anais de eventos, nos periódicos, nas dissertações e teses, quanto nas pesquisas independentes, nos ensaios, nas produções monográficas nos relatos de experiência. Podemos nos debruçar nas referências teóricas que sustentam as políticas públicas de educação e educação física no Brasil e veremos que são evidentes, o recuo da teoria, as imposturas intelectuais, a capitulação intelectual, enfim a retirada da intelectualidade da frente de batalha pela revolução socialista.

$\mathrm{O}$ que fazer, quais seriam os desafios a enfrentar para sintonizar uma busca constante da perspectiva teleológica de construção do comunismo, enquanto modo de organizar a produção e reprodução da vida, e da perspectiva epistemológica marxista na produção do conhecimento cientifico na educação e na educação física.

Tonet (2007) ressalta que temos que combater a atual forma de sociabilidade no marco do capital, e que toda a atividade educativa deve ter em seu horizonte norteador a emancipação humana que consiste em homens livres, senhores de seu destino, sujeitos da história em outra forma de sociabilidade com base no trabalho associado. Sociedade onde produtores associados de forma livre, consciente e coletiva controlam o processo de produção e distribuição da riqueza, forma ampla e profunda onde os homens 
terão a regência - na forma mais ampla e profunda humanamente possível o processo histórico. Formar, portanto, pessoas comprometidas com a transformação radical da sociedade.

Contraditoriamente, vivemos em um tempo histórico de enormes desafios, principalmente na América Latina. Enormes desafios locais, regionais, nacionais e internacionais no campo educacional, nas relações de trabalho, frente aos avanços do imperialismo, fase superior do capitalismo, com suas conseqüências parasitárias nefastas, destrutivas e nos cabe estabelecer referências de rupturas, de quebra de ilusões e de combate ao fetichismo. Ruptura com paradigmas teóricos que iludem, mais do que apóiam a elaboração de conhecimentos científicos (Duarte, 2003), quebra de ilusões nas idéias de igualdade, fraternidade e democracia burguesa (Chomsky, 1999), do fetichismo do Estado-de-Bem-Estar-Social, que em tempos de ditadura do capital em sua fase superior, o imperialismo (Lênin, 2007b), tem servido muito mais para transferir obrigações à sociedade civil do que garantir direitos constitucionais. Combate ao fetichismo da técnica e da tecnologia (Lessa, 2007) que, por si só, em uma sociedade de classes, não resolve os problemas de fundo a respeito da subsunção do trabalho ao capital, das guerras imperialistas (Coggiola, 1996; Petras, 2002) e da garantia do direito à educação e ao esporte, socialmente referenciados para todos. A estes desafios se agregam o combate ao individualismo (Duarte, 2004), ao primado do mérito pessoal, ao competitivismo, ao produtivismo, ao pragmatismo do pós-modernismo e do subjetivismo, para reconstruir esperanças (Freitas, 2005). Estas rupturas necessárias não se darão sem enfrentamentos, sem disputas, sem embates, porque a educação e a educação física, pelo impacto do neoliberalismo (Boron, 2004) é alvo dos interesses de acordos comerciais internacionais que entram na escola sim e fazem dela mais um fator de rendimento ao capital. Referências políticas se fazem necessárias para trabalhar na educação e na educação física, enfim, um projeto histórico socialista que enfrente as táticas ultrapassadas e esgarçadas do pacto social liberal, dos consensos de classe, estratégia do capital para manter a hegemonia (Neves, 2005). Nesse sentido, reafirmamos 
o marxismo e o socialismo revolucionário (Engels, 1990) porque não perderam qualquer atualidade, apesar da necessidade histórica de compreendermos o conteúdo da luta entre as classes sociais nesse início de milênio. As reafirmamos para distinguirmos as ditas esquerdas que continuam a se afastar, cada vez mais, da teoria que deveria alimentar as suas práticas, do que realmente são medidas de esquerda. Reafirmamos a teoria marxista, a pedagogia socialista, ou seja, a teoria pedagógica critica da prática da escola capitalista, que surge dentro dos limites das correlações de força existentes numa determinada formação social, a partir das próprias categorias que representam o movimento real dessa prática, incluídas suas contradições e formas de superação.

\section{Conclusão provisória - o desafio da razão: manifesto para a renovação teórica da educação e educação física baseado no marxismo}

Provavelmente, poderemos constatar na área da educação e educação física, assim como em outras áreas das ciências sociais e humanas, que continua hegemônica a interpretação do mundo, à luz de um relativismo absoluta, do niilismo, diluindo-se e despoltizando-se; a força ideológica, política e produtiva do conhecimento científico, em beneficio da classe capitalista. Reafirmamos, continua sendo necessário reverter a sentença constatativa de Marx nas Teses contra Feuerbach, "Até agora, os filósofos não fizeram mais do que interpretar o mundo; trata-se de mudá-lo”. Provavelmente, a maioria dos intelectuais não querem mais mudar o mundo. Os que queriam mudar o mundo o fizeram com base na referência marxista e queriam mudar o mundo junto com os movimentos operários e socialistas; movimentos que se transformariam, em grande medida devido à influência do marxismo, em forças políticas de massas.

Provavelmente, no Brasil, somos capazes, também, de verificar pelos fatos como os intelectuais deixaram de ser revolucionários sociais e, nunca foram ou deixaram de ser marxistas. Essa reação tem, provavelmente, na área de educação e educação física o aniquilamento da idéia de que é 
possível predizer, apoiados na análise histórica, o sucesso de uma forma particular de organizar a sociedade humana. Compromete-se assim a teleologia, o vir-a-ser. Também na educação e na educação física prevalecem apoiadas por teorias que se colocam na perspectiva pósmoderna a dissociação entre educação e educação física e a teleologia.

Diante de todos esses desvios, nos alerta Hobsbawm (2008) que "É tempo de restabelecer a coalizão daqueles que desejam ver na história uma pesquisa racional sobre o curso das transformações humanas, contra aqueles que a deformam sistematicamente com fins políticos e simultaneamente, de modo mais geral, contra os relativistas e os pós-modernos que se recusam a admitir que a história oferece essa possibilidade". Está em curso a transição do capitalismo ao socialismo (Trotsky, s.d.) o que deverá influenciar a virada teórica, não para "pós”, ou "neo", mas, sim, para os clássicos, da qual o marxismo constituiu um elemento importante, apesar de que isso nem sempre foi totalmente reconhecido. Marx influenciou a história principalmente através dos historiadores e dos pesquisadores em ciências sociais que retomaram as questões que ele colocava, tenham eles trazido, ou não, outras respostas. Portanto, o ponto de vista marxista é um elemento necessário para a reconstrução da frente da razão, como foi nas décadas de 1950 e 1960.

Neste momento em que o imperialismo - fase superior do capitalismo (Lenin, 2007) - assume seu teor mais dramático, é inaceitável, por exemplo, que a academia continue a negar as categorias e leis da dialética materialista histórica, continue a se valer de concepções teóricas idealistas e do relativismo epistêmico, que desestimulam, enfraquecem e desmobilizam a força e a unidade da luta de classes, atrasando a revolução proletária que deverá "livrar a humanidade de um sistema de produção condenado" (Sokol In Lenin, 2007, p. 186).

A passagem do imperialismo à revolução socialista continua encontrando como obstáculo os que defendem a "transformação social" somente nas palavras, afastando de fato a possibilidade de conquista do poder político por parte dos trabalhadores e do avanço no enfrentamento das 
contradições, visíveis nos espaços e tempos onde as contingências podem indicar possibilidades qualitativamente superiores, como, por exemplo, no trabalho pedagógico de produção do conhecimento cientifico. Mais do que ontem, faz-se hoje premente a necessidade de combater o simplismo, as imposturas intelectuais - o "uso abusivo dos conceitos da ciência pelos filósofos pós-modernos" (Sokal e Bricmont, 1999) -, o desenraizamento do conhecimento de suas bases ontológicas; combater o idealismo progressista da neutralidade científica, da convivência pacífica entre antagônicos, do pluralismo em uma sociedade onde existem e são ocultadas as classes antagônicas, da eternidade do capitalismo, da naturalidade dos fenômenos sociais, da falência do socialismo, do fim do proletariado (Lessa, 2007), do fim da luta de classes, da perda de referências históricas (Mészáros, 2003), conforme sustentam as teses do fim da história (Anderson, 1989) e as teses da pós-modernidade (Anderson, 1999). Teses estas que se expressam de maneira hegemônica nas explicações sobre a educação. Neste sentido recolocamos conceitos históricos sem os quais não é possível refletir com radicalidade, no conjunto e na totalidade (Saviani, 1985) a problemática da Educação para além do capital.

Por fim, o conhecimento especial, denominado "científico", dentro do qual reconhecemos as teorias pedagógicas, surge da atividade prática humana - o trabalho - e se desenvolve baseado nela. O motor principal desse desenvolvimento é constituído pelas necessidades materiais de produção; portanto, pode-se afirmar que o desenvolvimento da ciência subordina-se ao Projeto Histórico e às relações econômicas predominantes por ele estabelecidas. É dessas relações que depende o ritmo do desenvolvimento científico e o aproveitamento das conquistas científicas inclusive nos campos da educação e da educação física. É preciso, portanto, avançar, superar dicotomias entre as quais a dicotomia entre ciências humanas e sociais como nos explica Mészáros em sua síntese sobre a concepção de ciência em Marx, assim,

[...] o homem, enquanto parte específica da natureza (um ser com necessidades físicas historicamente anteriores a todas as outras), precisa 
produzir para se manter. Para tanto, ele cria, necessariamente, neste processo, uma complexa hierarquia de necessidades 'não- físicas', que se tornam igualmente necessárias à satisfação de suas necessidades físicas originais. (Mészáros, 2006, p.79).

Essas explicações nos permitem superar a falsa dicotomia entre ciências humanas e ciências naturais, bem como, nos apropriarmos da defesa de Marx de uma ciência humana, uma ciência de síntese concreta integrada com a vida real. O ponto de vista dela é o ideal do homem nãoalienado, cujas necessidades 'reais humanas'- em oposição às necessidades 'inventadas especulativamente' como às necessidades 'abstratamente materiais', praticamente desumanizadas - determinam a linha de pesquisa em cada campo particular. As realizações dos campos particulares - guiadas desde o início pela estrutura referencial comum de uma 'ciência humana' não-fragmentada - são, então, reunidas numa síntese superior, que por sua vez determina as linhas subseqüentes de investigações nos vários campos (Ibdem, p.98).

Mas não vamos avançar com uma educação rebaixada, com atraso teórico e se continuarmos a destruir o pensamento e a atitude critica na escola. A destruição do pensamento crítico é um fruto dessa educação alienada. O pensamento crítico constitui uma prova das ações, resoluções, criações e idéias à luz de determinadas teorias, leis, regras, princípios ou normas e, também, da sua correspondência com a realidade. Shardakov (1978) assinala cinco condições para que se desenvolva essa mentalidade crítica: Possuir os conhecimentos necessários na esfera em que a atividade mental crítica deverá ser desenvolvida. Não se pode analisar criticamente aquilo sobre o qual não se possuem dados suficientes; estar acostumado a comprovar qualquer resolução, ação ou juízo emitido antes de considerá-los acertados; relacionar com a realidade as regras, leis, normas ou teorias correspondentes, o processo e o resultado da solução, a ação ou juízo emitido; possuir o suficiente nível de desenvolvimento no que diz respeito à construção dos raciocínios lógicos; ter suficientemente desenvolvida a personalidade: as opiniões, as convicções, os ideais e a independência na forma de atuar. 
Constatamos, por fim, que em oposição às teorias pedagógicas idealistas, reacionárias e anti-revolucionárias que sustentam como pilares para a educação o "aprender a aprender", "aprender a ser", "aprender a fazer", "aprender a conviver", etc., levantam-se sólidas proposições pedagógicas nas lutas dos movimentos, com destaque para o movimento campesino, que enfrentam os pilares mais gerais do capital a propriedade privada dos meios de produção, a super exploração do trabalho assalariado. Portanto, podemos concluir que uma consistente base teórica materialista dialética histórica, a consciência de classe, a formação política e a organização revolucionária são elementos centrais para a escolarização de uma nação que se quer soberana, digna e com seu povo feliz. Isto passa necessariamente pelo domínio dos meios e do produto do processo de produção do conhecimento científico. Daí a necessidade vital da escola pública laica, de qualidade socialmente referenciada em todos os graus e níveis de ensino. Da educação infantil a pós-graduação.

Destacamos, portanto, para os estudos e debates os conceitos básicos para compreendermos e propormos o materialismo histórico dialético enquanto possibilidade epistemológica, o marxismo como filosofia e o comunismo como projeto histórico, enquanto base e fundamentação de propostas educacionais e de proposição pedagógica. Segundo Kopnin (1972) na ciência, enquanto sistema de conhecimento, a relação entre os conceitos se estabelece com base nos princípios aprovados pela prática, conceitos basilares e axiomas que expressam a idéia de uma dada ciência. A ciência é a unidade orgânica do conhecimento, unidade que surgiu por efeito de lei. Seu princípio unificador é o método, que absorveu toda a história antecedente do conhecimento do objeto. O ideal contido no conhecimento nos indica o autor, é uma forma especial de atividade do sujeito. E se sob a linguagem da teoria científica não conseguimos descobrir esse conteúdo, então a nossa análise não atingiu sua meta. Vale destacar, para enfrentar o idealismo teórico, que a chamada interpretação epistemológica, com o concurso do dispositivo categorial, inclui a linguagem da teoria científica no processo geral de movimento do conhecimento, no desenvolvimento 
intelectual da humanidade. Enquanto linguagem, nenhuma teoria pode ser exposta ou entendida como sistema de conhecimento humano se ao interpretá-la for aplicado apenas seu próprio dispositivo categorial. Por isto, concomitantemente com a linguagem de uma dada teoria e o dispositivo lógico formal da análise, as categorias filosóficas constituem, indiscutivelmente, um acervo indispensável de meios de interpretação da linguagem da teoria científica, situada na crítica a práxis da humanidade, ou seja, do real concreto apreendido pelo pensamento - o concreto pensado. Ao fragmentar a filosofia, a lógica, a ciência e a teoria do conhecimento, para formular explicações, os idealistas negam com isto a coincidência entre dialética, lógica e teoria do conhecimento, negam o movimento do pensamento como reflexo subjetivo e objetivo do real, negam a natureza social da filosofia, da lógica da ciência, negam com isto os fundamentos lógico-gnosiológicos da realização prática do conhecimento (Kopnin, 1972). Separam com isto as premissas teóricas das programáticas e tornam-se obstáculos à revolução das relações entre trabalho-capital, trabalhoeducação. Vale destacar que esta subsunção e sua manutenção, pela alienação (Mészáros, 2005; 2006), aprendem-se na escola, inclusive nas aulas na pós-graduação. Enfrentar a alienação com o estudo sistemático e rigoroso na base do materialismo histórico dialético justifica, portanto, a própria pós-graduação e seus grupos de pesquisa.

Enfim, com base no real, nos fatos, nos argumentos reafirmamos nossas hipóteses:

a) prevalecem, hegemonicamente no Brasil, teorias reformistas, antirevolucionarias, tanto na produção do conhecimento quanto nos subsídios de política pública nas áreas de educação, educação física e esporte o que pode ser constatado nos aportes teóricos mencionados nos textos, relatórios, projetos, programas e demais documentos, onde são silenciados os aspectos referentes as leis gerais que regem o modo do capital organizar a vida; do Estado burguês e da necessidade histórica de derrubá-lo, dos hábitos de vida burguesa em família e a necessidade de destruí-los e, a estratégia e tática na luta de classes para superação do capitalismo rumo ao comunismo. 
b) é necessário avançar, reagir, resistir, por rupturas e saltos qualitativos, para novas sínteses em patamares teórico-práticos mais elevados, superando os desvios teóricos, rompendo ilusões, lutando contra o fetichismo, o irracionalismo e o idealismo, e isto passa sim pelo domínio da lógica e teoria do conhecimento materialista histórica dialética, passa pelo marxismo;

c) existem reações, sim, na luta concreta, que buscam construir e erguer outros pilares para a produção do conhecimento científico e para a escolarização, e esses pilares já podem ser reconhecidos e são: o combate ao irracionalismo, ao pós-modernismo, aos "giros" e "viradas" idealistas, buscando consolidar uma consistente base teórica marxista, avançar na consciência de classe, na formação política e na organização revolucionária, como contra-ponto aos pilares da educação defendidos pela UNESCO para o mundo.

d) ventos de esquerda ainda sopram na América Latina, contraditoriamente, e o marxismo, enquanto filosofia, o materialismo histórico dialético enquanto epistemologia e, o socialismo enquanto projeto histórico, estão recolocados, mais fortes do que nunca, pela sua aderência ao real, como referencia para tratarmos da produção do conhecimento científico e das políticas públicas na perspectiva do projeto histórico para além do capital.

\section{Referências}

ANDERSON, P. Considerações sobre o marxismo ocidental. 2. ed. São Paulo: Brasiliense,1989.

ANDERSON, P. As origens da pós-modernidade. Rio de Janeiro: Jorge Zahar, 1999.

BETTO, F. Somos todos pós-modernos? 2008. Disponível em: http://www.correiocidadania.com.br/content/view/2314/55/.

BOGO, A. Identidade e luta de Classes. São Paulo: Expressão Popular, 2008.

BONOT'TO, E. L. Ciência para além do neoliberalismo e do determinismo tecnológico. Revista Princípios, nº45, maio de 1997, pp. 72-81. 
BORON, A. (Org.). Nova hegemonia mundial: alternativas de mudanças e movimentos sociais. Clacso, 2004.

CHEPTUlin, A. A dialética Materialista: Categorias e leis da dialética. São Paulo: Alfa-Omega, 1982.

CHOMSKY, N. A minoria próspera e a multidão inquieta. Brasília: Editora da UnB, 1999.

COGGIOLA, O. (Org.) Marxismo hoje. São Paulo: Xamã, 1996.

DELORS, J. Educação: Um tesouro a descobrir. Relatório da Comissão internacional sobre educação para o século XXXI. UNESCO, 1998.

DUARTE, N. Educação Escolar, Teoria do Cotidiano e a Escola de Vigotski. 3. ed. Campinas-SP: Autores Associados, 2001.

DUARTE, N. Sociedade do Conhecimento on Sociedade das Ilusões? Quatro Ensaios Crítico-Dialéticos em Filosofia da Educação. 1. ed. Campinas: Autores Associados, 2003. 110 p.

DUARTE, N. (Org.). Crítica ao Fetichismo da Individualidade. 1. ed. Campinas: Autores Associados, 2004. v. 1. 242 p.

EAGLETON. T. As ilusões do pós-modernismo. Rio de Janeiro: Jorge Zahar, 1998.

ENGELS, F. O Papel do Trabalho na Transformação do Macaco em Homem. $4^{\mathrm{a}}$ ed. São Paulo: Global, 1990.

EVANGELISTA, J. E.. Crise do Marxismo e Irracionalismo Pós Moderno. São Paulo: Cortez, 1992.

FREITAS, L. C. de. Uma pós-modernidade de libertação: reconstruindo as esperanças. Campinas-SP: Autores Associados, 2005.

FRIGOTTO, G. Educaşão e a crise do capitalismo real. São Paulo: Cortez, 1996.

FRIGOTTO, G. (Org.). Educação e crise do trabalho: perspectivas de final de século. Petrópolis (RJ): Vozes, 1998.

GHIRALDELLI JÚNIOR, P. Virada Lingüistica. 2004. Disponível em: http://ghiraldelli.multiply.com/journal/item/112. Acessado em: 20 de novembro de 2008, às 19:27.

HOBSBAWM, E. A Era dos extremos. O breve século XX: 1914-1991. São Paulo, Companhia das Letras, 1995. 
HOBSBAWM, E. O desafio da rąãa: manifesto para a renovação da história. 11 de abril de 2008.2 Disponível em: http://www.cartamaior.com.br/templates/materiaMostrar.cfm?materia id=14 924. Acessado em: 8 de dezembro de 2008, às $14 \mathrm{H}$.

JAMESON, F. Pós-modernismo: a lógica cultural do capitalismo tardio. 2ed. São Paulo: 1997.

KOPNIN, P. V. Fundamentos lógicos da Ciência. Rio de Janeiro: Civilização Brasileira, 1972.

KOSIK, K. Dialética do Concreto. Rio de Janeiro: Paz e Terra, 1976.

KUENZER, A. Z. Desafios Teórico-metodológicos da relação trabalhoeducação e o papel social da escola. In: FRIGOTTO, Gaudêncio. (Org.). Educação e crise do trabalho: perspectivas de final de século. Petrópolis - RJ: Vozes, 1998.

KURZ, R. Razão Sangrenta: 20 Teses contra o assim chamado Iluminismo e os "valores ocidentais". Krisis 25 - Junho de 2002. Disponível em: http://obeco.planetaclix.pt/rkurz103.htm

LEHER, R. Projetos e modelos de autonomia e privatização das universidades públicas. In: GENTILI, Pablo. (Org). Universidades na penumbra: neoliberalismo e reestruturação universitária. São Paulo: Cortez, 2001.

LENIN, V. I. O Imperialismo fase superior do capitalismo. Brasília: Nova Palavra, 2007.

LESSA, S. Trabalho e proletariado no Capitalismo Contemporâneo. São Paulo: Cortez, 2007.

LIMA, K. R. de S. e MARTINS, A. S. Pressupostos, Princípios e Estratégias. In: NEVES, L. M. W. (org.). A Nova Pedagogia da Hegemonia: Estratégias do Capital para Educar o Consenso. São Paulo: Xamã, 2005.

LOMBARDI, J. C. Globalização, pós-modernidade e educação. Campinas: Autores Associados, 2003.

LOMBARDI, J. C. e SANFELICE, J. L. Liberalismo e educação em debate. São Paulo: Autores Associados, 2007.

LOMBARDI, J. C. e SAVIANI, D. Marxismo e educaşão: debates contemporâneos. Campinas-SP: Autores Associados, 2005.

LYOTARD, J. F. A condição pós-moderna. Rio de Janeiro: José Olympio, 1990. Título original: La condition postmoderne. (1979).

MARTINS, J. Os limites do irracional. Globalização e crise econômica mundial. 
São Paulo: Fio do Tempo, 1999.

MARX, K. Contribuição à crítica da economia política. $2^{\circ}$ ed. São Paulo: Martins Fontes, 1983.

MARX, K. Formações econômicas pré-capitalistas. 5ed. Rio de Janeiro: Paz e Terra, 1986.

MARX \& ENGELS. A Ideologia Alemã, Lisboa: Avante, 1981.

MELO, A. A. S. A mundialização da educação: consolidação do projeto neoliberal na América Latina: Brasil e Venezuela. Maceió: Edufal, 2004.

MÉSZÁROS, I. Filosofia, ideologia e ciência social. São Paulo: Ensaio, 1993.

MÉSZÁROS, I. Para Além do Capital. São Paulo: Boitempo, 2002.

MÉSZÁROS, I. O século XXI: socialismo ou barbárie? São Paulo: Boitempo, 2003.

MÉSZÁROS, I. A educação para além do capital. São Paulo: Boitempo, 2005.

MÉSZÁROS, I. A teoria da Alienação em Marx. São Paulo: Boitempo, 2006.

MORAES, M. C. M. Iluminismo às avessas: produção de conhecimento e políticas de formação docente. Rio de Janeiro: DP\&A, 2003.

MORIN, E. Os sete saberes necessários à educação do futuro. 3a. ed. São Paulo: Cortez; Brasília-DF: UNESCO, 2001.

NETTO, J. P. Marxismo Impenitente: Contribuições à história das idéias marxistas. São Paulo: Cortez, 2004.

NEVES, L. (Org.). A Nova Pedagogia da hegemonia: estratégias do capital para educar o consenso. São Paulo, Xamã, 2005.

PETRAS, J. Império e politicas revolucionárias na América Latina. São Paulo, Xamã, 2002.

PETRAS, J. Os intelectuais: uma crítica marxista aos pós-marxistas. Plural. Revista dos Professores da UFSC-SSIND, n. 8, Ano 5/dez. 1996 a.

PETRAS, J. Os intelectuais em retirada. In: COGGIOLA, O. (Org.). Marxismo hoje. São Paulo: Xamã, 1996b, p.16-20

PUCCI, B. Teoria crítica e Educação. Rio de Janeiro, Vozes, 1995.

SADER, E. Movimentos Sociais na Transicao Democratica. São Paulo, SP: Cortez, 1987. 
SALAZAR, L. S. Madre América: um siglo de Violência y dolor (1898-1998). Habana, Cuba: Editorial de Ciências Sociales, 2006.

SÁNCHEZ. GAMBOA, S. O debate da pós-modernidade: as teorias do conhecimento em jogo. 2009 - a. Disponível em: http://www.cbce.org.br/br/gtt/texto.asp?id=4;

SÁNCHEZ. GAMBOA, S. Reações ao giro lingüistico. Apresentação. 2009 - b. Disponível em: http://www.cbce.org.br/upload/file/gttepistemologia/REACCÕES $\% 20 \mathrm{AO} \% 2$ 0GIRO $\% 20$ LINGUÍSTICO $\% 20$ Silvio\%20Sánchez $\% 20$ Gamboa.pdf.

SANTOS, J. F. O que é Pós-Modernismo. São Paulo: Brasiliense, 2006.

SAVIANI, D. Escola e democracia. 8. ed. São Paulo: Cortez e Editores Associados, 1985.

SHARDAKOV, M. N. Desarrollo del pensamiento en el escolar. La Habana: Editorial de Libros para la Educación, 1978.

SOBRAL, F. A. da F. A produção e a apropriação social da pesquisa científica e tecnológica: uma discussão no capitalismo dependente. Revista Brasileira de Estudos Pedagógicos, Brasília, v. 67, n. 156, p. 287-305, maio/ago. 1986.

SOKAL, A. e BRICMONT, J. Imposturas, intelectuais: o abuso da ciência pelos filósofos pós-modernos. Rio de Janeiro: Record, 1999.

SOKOL, M. Prefácio. In: LÊNIN, V. I. O Imperialismo, Fase Superior do Capitalismo. Brasília: Nova Palavra, 2007

SOUZA, J. F. Os desafios educacionais no Nordeste e a responsabilidade dos Centros de Educação e suas Universidades Públicas. Cadernos do Centro de Educação. Recife. Ano 1, n. 1, Março de 1997.

TOMMASI, L.; WARDE, M.; HADDAD, S. (Org.). O Banco Mundial e as politicas Educacionais. 2.ed. São Paulo: Cortez, 1996.

TONET, I. Educação contra o capital. Maceió: edUFAL, 2007.

TROTSKY, L. Em defesa do marxismo. São Paulo: Proposta, s.d.

TROTSKY, L. Questões do modo de vida. Publicações Liga Bolchevique Internacionalista. 1923.

TROTSKY, L. Programa de Transição. São Paulo: Comissão de Formação, 1995. $55^{\circ}$ Aniversário do assassinato de Trotsky e $100^{\circ}$ Aniversário da Morte de F. Engels.

WOOD, E. M. e FOSTER, J. B. Em defesa da História: Marxismo e pós- 
modernismo. Rio de Janeiro: Zahar, 1999.

ZAIDAM FILHO, M. Crise da razão histórica. Campinas-SP: Papirus, 1989. 